\title{
EFEK HIPOLIPIDEMIK ALPUKAT (Persea americana) PADA HIPERKOLESTEROLEMIA: LITERATUR REVIEW
}

\author{
Nadila Ayuni Putri ${ }^{1 *}$, Mira Sri Gumilar ${ }^{2}$ \\ ${ }^{1}$ Program Studi Pendidikan Dokter, Fakultas Kedokteran, Universitas Lampung, Lampung \\ ${ }^{2}$ Jurusan Keperawatan Gigi Poltekkes Kemenkes Jambi \\ *Korespondensi penulis: nadilaayuni1998@gmail.com
}

\begin{abstract}
ABSTRAK
Pendahuluan: Saat ini, Indonesia memiliki masalah kesehatan baik berupa penyakit menular maupun penyakit tidak menular (PTM). Salah satu faktor risiko terjadinya PTM adalah kadar kolesterol yang tinggi di dalam darah (hiperkolesterolemia). Meningkatnya kadar kolesterol dapat menimbulkan masalah kesehatan seperti batu empedu, hipertensi, stroke hingga serangan jantung. Di Indonesia, berdasarkan data Riset Kesehatan Dasar (Riskesdas), prevalensi penderita hiperkolesterol pada usia diatas 15 tahun di tahun 2013 sebesar 35,9\% dan menurun prevalensinya di tahun 2018 sebesar 28,8\%. Walaupun berdasarkan data Riskesdas hiperkolesterol mengalami penurunan, namun angka ini masih diatas angka prevalensi hiperkolesterol di Asia Tenggara pada tahun 2013 dan berada sedikit dibawah prevalensi asia tenggara pada tahun 2018 sehingga berdasarkan data-data tersebut, hiperkolesterol menjadi salah satu masalah kesehatan di Indonesia.

Isi : Hiperkolesterol dapat diturunkan dengan menggunakan obat-obatan seperti golongan statin dan fibrat. Dalam penggunaan jangka panjang, obat-obatan tersebut memberikan berbagai efek samping. Sebagai alternatifnya digunakan makanan yang mengandung komponen bioaktif yang berguna untuk mengontrol kadar kolesterol. Salah satunya adalah buah alpukat. Alpukat sangat direkomendasikan oleh AHA dalam panduan pola hidup untuk menurunkan risiko penyakit kardiovaskular. Buah ini disebut juga buah yang bebas kolestrol karena banyak mengandung MUFA. Tidak hanya buahnya, berdasarkan beberapa studi pada tikus, bahkan telah membuktikan bahwa ekstrak daun alpukat dan bijinya memiliki efek antihiperlipidemia. Selain memberikan manfaat buah alpukat juga memiliki kekurangan, namun apabila dibandingkan manfaatnya, maka manfaat dari buah alpukat jauh lebih besar dibandingkan dengan kekuranganya.

Kesimpulan: Konsumsi buah alpukat (Persea americana) dapat menurunkan kadar LDL dan trigliserid sehingga menurunkan hiperkolesterolemia.
\end{abstract}

Kata Kunci: alpukat; hiperkolesterolemia.

\section{HYPOLIPIDEMICEFFECT OF AVOCADO (PERSEA AMERICANA) ON HIPERCHOLESTEROLEMIA: LITERATURE REVIEW}

\begin{abstract}
Background: Indonesia has health problems nowadays in the form of both communicable and non-communicable diseases (PTM). One risk factor for PTM is high cholesterol levels in the blood (hypercholesterolemia). Increased cholesterol levels can cause health problems such as gallstones, hypertension, strokes to heart attacks. In Indonesia, based on Basic Health Research (Riskesdas) data, the prevalence of hypercholesterolemia at the age of 15 years in 2013 was 35.9\% and the prevalence in 2018 decreased by 28.8\%. Although based on the Riskesdas hypercholesterolemia data has decreased, but this figure is still above the prevalence of hypercholesterolemia in Southeast Asia in 2013 and is slightly below the prevalence of southeast Asia in 2018 so based on these data, hypercholesterolemia is one of the health problems in Indonesia.

Content: Hypercholesterol can be reduced by using drugs such as statins and fibrates. In long-term use, these drugs have various side effects. As an alternative use foods that contain bioactive components that are useful for controlling cholesterol levels. One of them is avocado. Avocados are highly recommended by AHA in lifestyle guidelines to reduce the risk of cardiovascular disease. This fruit is also called cholesterol-free fruit because it contains MUFA. Not only the fruit, based on several studies in mice, has even proven that avocado leaf extract and its seeds have an antihyperlipidemic effect. In addition to providing the benefits of avocados also has disadvantages, but when compared to the benefits, the benefits of avocados are far greater than the disadvantages.

Conclusion: Consumption of avocados (Persea americana) can reduce LDL and triglyceride levels, thereby reducing hypercholesterolemia.
\end{abstract}

Keywords: Avocado, Hypercholesterolemia 


\section{PENDAHULUAN}

Saat ini, Indonesia memiliki masalah kesehatan baik berupa penyakit menular maupun penyakit tidak menular (PTM). Hasil Riset Kesehatan Dasar (Riskesdas) tampak kecenderungan peningkatan penyakit tidak menular dari hasil Riskesdas tahun 2007 sampai tahun 2013. Salah satu faktor risiko terjadinya PTM adalah kadar kolesterol yang tinggi di dalam darah (hiperkolesterolemia). ${ }^{1}$

Meningkatnya kadar kolesterol dapat menimbulkan masalah kesehatan seperti batu empedu, hipertensi, stroke hingga serangan jantung. WHO menyatakan bahwa secara global, hiperkolesterol merupakan urutan ketiga penyebab jantung iskemik. Diperkirakan di seluruh dunia, peningkatan kolesterol dapat menyebabkan 2,6 juta kematian ( menyumbang $4.5 \%$ dari total kematian dan menyebabkan 29,7 juta orang menderita cacat (menyumbang 2\% dari angka kecacatan). Hiperkolesterolemia menjadi penyebab utama beban penyakit baik di negara maju maupun di negara berkembang. ${ }^{2,3}$

Data dari WHO menunjukan prevalensi kolesterol di seluruh dunia sebesar 39\%. Wilayah WHO dengan Prevalensi kolesterol paling tinggi adalah di wilayah eropa yaitu sebesar $54 \%$, kemudian selanjutnya di wilayah Amerika sebesar $48 \%$ dan prevalensi terendah di asia tenggara sebesar $29.0 \%$. $^{3}$

Di Indonesia, berdasarkan data Riset Kesehatan Dasar (Riskesdas), prevalensi penderita hiperkolesterol pada usia diatas 15 tahun di tahun 2013 sebesar 35,9\% dan menurun prevalensinya di tahun 2018 sebesar 28,8\%. Masalah gangguan kolesterol di tahun 2018 mencakup kadar kolesterol borderline dan kadar kolesterol yang tinggi. ${ }^{4,5}$ Walaupun berdasarkan data Riskesdas hiperkolesterol mengalami penurunan, namun angka ini masih diatas angka prevalensi hiperkolesterol di Asia Tenggara pada tahun 2013 dan berada sedikit dibawah prevalensi asia tenggara pada tahun 2018 sehingga berdasarkan data-data tersebut, hiperkolesterol menjadi salah satu masalah kesehatan di Indonesia.

Hiperkolesterol dapat diturunkan dengan menggunakan obat-obatan seperti golongan statin dan fibrat sering digunakan sebagai tetalaksana hiperkolesterolemia namun dalam penggunaan jangka panjang, obat-obatan tersebut memberikan berbagai efek samping. Sebagai alternatifnya digunakan makanan yang mengandung komponen bioaktif yang berguna untuk mengontrol kadar kolesterol. Salah satunya adalah buah alpukat. ${ }^{6-8}$
Mengkonsumsi buah-buahan dan sayur dapat menurunkan risiko terjadinya berbagai penyakit. Alpukat (Persea americana) telah secara luas digunakan karena memiliki berbagai efek farmakologis salah satunya memiliki efek antihiperlipidemia. Buah ini memiliki komponen aktif yang dapat menurunkan kadar kolesterol dalam darah seperti pantethin, niacin (vitamin B3), vitamin C, vitamin E, vitamin A, pantogenic acid, MUFA, dan selenium. ${ }^{9-11}$

Literatur review ini bertujuan untuk memberikan gambaran mengenai efek hipolipidemik alpukat terhadap penurunan kadar kolesterol sehingga dapat menjadi alternatif dalam upaya pencegahan dan pengobatan tradisional pada keadaan hiperkolesterolemia.

\section{Definisi}

Kolesterol merupakan zat seperti lilin yang berupa lemak dan ditemukan pada semua sel dalam tubuh. Kolesterol yang selama ini menjadi zat yang dipandang negatif, sebenarnya sangat dibutuhkan oleh tubuh manusia untuk membentuk hormon, vitamin $\mathrm{D}$, dan asam empedu. Kebutuhan kolesterol tentunya dalam kadar yang normal, ketika kadarnya meningkat di dalam darah, maka kolesterol akan menjadi zat yang berbahaya bagi tubuh. Kadar kolesterol total yang normal dalam darah adalah kurang dari $200 \mathrm{mg} / \mathrm{dl}$,. Apabila kadarnya mencapai 240 $\mathrm{mg} / \mathrm{dl}$ atau lebih maka terjadi peningkatan kadar kolesterol disebut hiperkolesterolemia. ${ }^{12}$

Hiperkolesterolemia adalah gangguan metabolisme lipid yang menjadi faktor risiko terbesar untuk berkembang menjadi peyakit perlemakan hati (fatty liver) dan aterosklerosis. Hiperkolesterolemia adalah bentuk hiperlipidemia yang biasanya asimtomatik dan berlangsung lama. Penyakit ini biasanya disebabkan oleh karena konsumsi makanan yang tinggi kolesterol dan asam lemak jenuh atau lemak trans yang dapat menstimulasi adanya peningkatan stres oksidatif. ${ }^{6,7,13}$

Hiperkolesterolemia ditetapkan apabila terjadi peningkatan kadar kolesterol total dalam plasma lebih dari $200 \mathrm{mg} / \mathrm{dl}$ dengan atau tanpa adanya peningkatan low-density lipoprotein (LDL) dan trigliserid atau penurunan non-highdensity lipoprotein (HDL). Hal ini disebut juga dengan dislipidemia. Hiperkolesterolemia memiliki risiko yang sangat tinggi terserang penyakit kardiovaskular. Rekomendasi kadar kolesterol total pada plasma adalah $200 \mathrm{mg} / \mathrm{dl}^{14}$ 16 
Tanaman Alpukat (Persea americana Mill) merupakan tanaman yang bukan asli Indonesia. Tanaman ini berasal dari Amerika Tengah dan diperkirakan masuk ke Indonesia pada abad ke-18. Tanaman alpukat merupakan tanaman yang tumbuh dengan baik di wilayah beriklim tropis termasuk Indonesia. ${ }^{17}$

\section{Faktor Risiko Terjadinya Hiperkolesterolemia}

Makanan adalah faktor utama yang mempengaruhi kesehatan dan kualitas hidup. Saat ini, masyarakat memiliki pola diet tinggi konsumsi daging yang mengandung lemak, gula dan makanan siap saji dibandingkan dengan buah sayuran dan lemak tak jenuh. Hal ini memicu berbagai penyakit degeneratif seperti obesitas, diabetes, penyakit kardiovaskular dan hiperkolesterolemia.

Asam lemak dalam makanan terdiri atas empat kategori yaitu asam lemak jenuh, lemak trans, polyunsaturated fatty acid (PUFA), dan monosaturated fatty acid (MUFA). Walaupun menurunkan konsumsi lemak secara umum direkomendasikan untuk menurunkan kadar lemak dalam darah, namun mengubah jenis lemak yang dikonsumsi lebih direkomendasikan dalam memodifikasi faktor dislipidemia. Jenis lemak yang paling sering dikonsumsi adalah asam lemak jenuh dan trans. Dengan mengganti lemak yang dikonsumsi menjadi PUFA dan MUFA akan menurunkan risiko terjadinya CHD sebesar 19\%. Dalam Diaetary Guidelines for Americans merekomendasikan total lemak yang dikonsumsi pada orang dewasa diatas 18 tahun adalah 20\%-30\% dari total kalori, dimana dalam panduan tersebut asam lemak jenuh dan trans yang boleh dikonsumsi hanya sebesar 7\% dari kalori. Sementara menurut American Heart Association (AHA) menurunkan konsumsi asam lemak jenuh sebesar 5\%-6\% dari total kalori yang dikonsumsi dapat menurunkan risiko penyakit kardiovaskular. ${ }^{18-20}$

Penelitian yang dilakukan oleh Maratu Soleha menunjukan bahwa kadar hiperkolesterolemia dapat dipengaruhi oleh Index Massa Tubuh (IMT), tekanan darah, kebiasaan merokok, dan aktifitas fisik. Pada penelitian tersebut, subjek dengan kelompok IMT obesitas derjarat 2 memiliki risiko 1,39 kali untuk mengalami hiperkolesterol dibandingkan dengan subjke pada kelompok IMT normal. Subjek yang memiliki tekanan darah tinggi derajat dua memiliki risiko hiperkolesterolemia sebesar 1,88 kali lebih tinggi dibandingkan dengan subjek yang memiliki tekanan darah normal. Pada subjek yang memiliki kebiasaan merokok 13-22 batang per hari memiliki risiko hiperkolesterolemia sebesar 1,16 kali lebih besar dibandingkan dengan subjek yang merokok 1-3 batang per hari. Subjek yang tidak melakukan aktifitas berat memiliki risiko 1,31 kali untuk mengalami hiperkoleterolemia dibandingkan dengan subjek yang melakukan aktifitas berat. ${ }^{21}$

\section{Patofisiologi Hiperkolesterol pada Pembuluh Darah}

Total kolesterol terdiri atas komponen HDL, LDL, intermediate dencity lipoproteins (IDL), very low density lipoprotein (VLDL), kilomikron dan trigliserida. Kadar HDL yang tinggi memiliki korelasi yang kuat dalam menurunkan risiko penyakit kardiovaskular karena perannya sebagai anti-aterogenik. Kadar LDL dan trigliserid akan meningkatkan kadar kolestrol total sehingga terjadi hiperkolestrolemia. Sementara IDL, VLDL dan kilomikron juga berperan dalam pembuluh darah perifer, sehingga peningkatan kadar-kadar tersebut juga berhubungan dengan peningkatan kejadian coronary heart disease (CHD) karena sifatnya yang merupakan pro-aterogenik. ${ }^{22-24}$

Kolesterol dapat menempel di pembuluh darah dan mengganggu fungsinya. Ketika kolesterol menempel pada dinding endotel pembuluh darah akan menyebabkan timbulnya lesi, plak, oklusi dan emboli. Hal ini akan menyebabkan terhambatnya proses penyembuhan apabila ada iskemia. Endotel pembuluh darah dapat memproduksi berbagai bioaktif molekul. Dalam kondisi normal, sel-sel endotel akan menjaga suasana pembuluh darah dengan menghasilkan faktor-faktor yang merelaksasikan keadaan endotel seperti Nitrit Oxide, prostasiklin dan endothelium-derived hyperpolarizing factors sehingga menyeimbangkan apabila ada kontraksi pada pembuluh darah akibat sistem persarafan simpatik. Molekul-molekul ini juga berperan dalam homeostasis sistem pembuluh darah melalui penyesuaian dirinya terhadap kebutuhan aliran darah, proses koagulasi, inflamasi dan agregasi trombosit. Nitrit oxide berguna dalam sintesis asam amino L-arginine melalui enzyme nitrit oxide sintase (NOS) dan mengatur tahanan pembuluh darah melalui mekanisme mencegah aktivasi trombosit, mencegah stres oksidatif, pertumbuhan sel dan inflamasi. ${ }^{14,16}$ 
Adanya tumpukan lipoprotein seperti keadaan hiperkolesteromia dapat menyebabkan adanya disfungsi endotel sehingga berakibat pada kegagalan perfusi jaringan. Apabila terjadi kegagalan perfusi pada ginjal akan menyebabkan disfungsi kerja ginjal dan hipertensi. Apabila terjadi pada jantung akan menurunkan aliran darah ke jantung dan menyebabkan coronary heart disease. Menurunnya perfusi akibat disfungsi endotel juga dapat mengganggu kerja hepar sehingga menyababkan disfungsi hepatik yang mengakibatkan penyakit non-alkoholik fatty liver. ${ }^{25,26}$

\section{Terapi Farmakologi Hiperkolesterolemia}

Tatalaksana hiperkolesterolemia yang utama adalah pengaturan dalam konsumsi makanan yang tinggi kolesterol, lemak jenuh atau asam lemak trans yang dapat memicu stres oksidatif sehingga hilangnya antioksidan dalam endotel pembuluh darah. Tatalaksana yang biasa dilakukan adalah menurunkan kadar LDL dengan menambahkan obat-obatan. Secara farmakologis hiperkolesterol biasanya ditatalaksana menggunakan obat-obatan golongan statin (seperti atrovastatin, simvastatin, lovastatin dan rosuvastatin) dan fibrat (fenofibrat, clofibrat, bezafibrat dan ciprofibrat). Penambahan statin pada hiperkolesterolemia primer sebagai monoterapi sudah menjadi terapi utama. Terdapat pula tatalaksana terbaru yang dapat menurunkan kadar lipid dalam darah menggunakan antibodi monoklonal proprotein covertase subtilisin. Terapi tersebut telah disetujui oleh Food and Drug Administration and Europian Medicine Agency. Obat tersebut juga bekerja menurunkan kadar LDL dalam darah. Namun obat-obatan ini dapat memberikan efek samping apabila digunakan dalam jangka waktu yang lama seperti hepatotoksik dan miotoksik. $6,25,27$

Oleh karena itu diperlukan target-target terapi dalam penggunaan obat-obatan tersebut. Menurut Europian Clinical Practice Guidelines untuk target LDL dengan individu yang memiliki risiko penyakit kardiovaskular $<100 \mathrm{mg} / \mathrm{dl}$. Sementara untuk pasien tanpa risiko penyakit kardiovaskular tetapi memiliki riwayat diabetes melitus atau dengan risiko tinggi penyakit kardiovaskular memiliki target terapi yang lebih rendah yaitu $<70 \mathrm{mg} / \mathrm{dl}$. Bagaimanapun hanya menggunakan obat-obatan untuk menatalaksana penyakit hiperkolesterolemia sering kali tidak mencapai target terapi tersebut., 90

\section{Kandungan Alpukat yang Dapat Menurunkan Kolesterol}

Alpukat (Persea americanal) berasal dari kawasan subtropikal Amerika dan merupakan anggota dari laurel family. Buah ini adalah salah satu tumbuhan yang memiliki bahan aktif untuk menurunkan kadar kolesterol di dalam darah. Alpukat mengandung antioksidan seperti panthetin, niacin (vitamin B3), beta sitosterol, vitamin $\mathrm{C}$, vitamin A (beta carotene), vitamin $\mathrm{E}$, vitamin $\mathrm{K}$, pantothenic acid, oleic acid, folic acid, selenium, asam amino dan serat. Antioksidan tersebut dapat menurunkan kadar kolestrol dalam serum darah dan memiliki efek anti inflamasi. Alpukat banyak mengandung potensial oil (15-30 g/100 g buah) dan kebanyakan adalah MUFA yaitu sebesar 58,6\% dari jumlah keseluruhan total asam lemak yang dimiliki. ${ }^{11,28,29}$

Alpukat sangat direkomendasikan oleh AHA dalam panduan pola hidup untuk menurunkan risiko penyakit kardiovaskular. Buah ini disebut juga buah yang bebas kolestrol karena banyak mengandung MUFA. MUFA dapat menurunkan kadar LDL dan trigliserida serta meningkatkan HDL. Selain itu alpukat juga mengandung banyak beta sitosteol yang sangat dikenal dengan perannya sebagai agen antikolesterol. MUFA juga dapat menggantikan asam lemak jenuh dan berperan sebagai mikronutrien yang memiliki manfaat cardioprotective. Terdapat dua mekanisme yang menyebabkan MUFA dapat menurunkan kadar kolesterol pada plasma yaitu (1) adanya perubahan komposisi VLDL, (2) perubahan aktivitas enzim dan protein yang terlibat dalam intravaskular sehingga menyebabkan VLDL mengalami katabolisme dan menurunkan konsentrasi trigliserid pada plasma. ${ }^{25,26}$

Selain MUFA, alpukat juga mengandung beta sitosterol yang dapat menurunkan kadar kolesterol melalui mekanisme menghambat absorbsi kolesterol dan meningkatkan ekskresinya pada darah. Vitamin B3 dapat menurunkan produksi VLDL, sehingga menurunkan juga kadar IDL dan LDL yang akan berakibat pada turunkan kadar kolestrol dalam plasma. Vitamin $\mathrm{C}$ berperan dalam reaksi hidroksilasi pada pembentukan asam empedu sehingga meningkatkan eksresi kolesterol. ${ }^{14,15}$

Tidak hanya buahnya, berdasarkan beberapa studi pada tikus, bahkan telah membuktikan bahwa ekstrak daun alpukat dan bijinya memiliki efek antihiperlipidemia. Konsumsi ekstrak daun alpukat dengan dosis 20 $\mathrm{mg} / \mathrm{kgBB}$ dan $40 \mathrm{mg} / \mathrm{kgBB}$ memberikan efek yang signifikan dalam menurunkan total 
kolestrol, LDL dan meningkatkan HDL pada tikus. Sementara konsumsi ekstrak biji alpukat dengan dosis $125 \mathrm{mg} / \mathrm{kgBB}, 250 \mathrm{mg} / \mathrm{kgBB}$ dan $500 \mathrm{mg} / \mathrm{kgBB}$ memberikan efek yang signifikan dalam menurunkan kadar kolesterol pada tikus. Dalam menurunkan kadar kolesterol alpukat juga sudah banyak diolah menjadi avocado oil. Minyak ini memiliki berbagai komponen bioaktif seperti fitosterol, asam lemak tak jenuh, vitamin dan antioksidan. Suplementasi avocado oil dapat menurunkan kadar trigiliserid menjadi normal. Virgin avocado oil (VAO) adalah olahan alami alpukat dalam temperatur kurang dari $50^{\circ} \mathrm{C}$. VAO telah banyak digunakan sebagai suplementasi. Melalui pengolahan alpukat dengan temperatur tersebut, VAO mengandung komponen bioaktif yang mudah diserap oleh tubuh dan berguna bagi kesehatan. ${ }^{9,29}$

Berdasarkan segala manfaat yang didapatkan dengan mengkonsumsi alpukat, buah ini dapat memberikan efek yang signifikan dalam menurunkan kadar kolesterol dalam darah. Sehingga sangat direkomendasikan untuk dikonsumsi sebagai tatalaksana diet untuk hiperkolesterolemia.

\section{Kelebihan dan Kekurangan buah Alpukat sebagai Alternatif Obat Tradisional}

Selain menurunkan kolesterol, buah alpukat juga bermanfaat untuk meningkatkan aktifitas seksual, melancarkan menstruasi, meringankan osteoarthritis dan sebagai alternatif suplemen makanan. Alpukat sebagai makanan padat nutrisi memiliki peran penting dalam pola diet sehat. Buah Alpukat mengandung 20 vitamin, nutrisi dan phytonutrients sehingga menjadi sumber makanan yang baik untuk menurunkan kadar lemak di dalam tubuh termasuk kolesterol. Selain itu, alpukat dapat menurunkan kadar gula darah pada diabetes mellitus tipe 2 dan menurunkan kadar sodium di dalam darah. Untuk ibu hamil, buah alpukat mengandung asam folat yang penting dalam pembentukan neural tube bagi janin. ${ }^{30}$

Sebagai buah yang memiliki manfaat banyak, disisi lain buah alpukat juga memiliki efek samping. Alpukat dapat berinteraksi dengan obat warfarin sehingga jumlah konsumsi harus dibatasi pada orang yang mengkonsumsi warfarin karena akan meningkatkan penjedalan darah karena efektifitas warfarin menurun. ${ }^{31}$ Efek samping lainya, beberapa orang dapat muncul alergi terhadap buah alpukat terutama yang memiliki alergi terhadap latex. Efek toksisitas dari buah alpukat sangat rendah. Kekurangan lain dalam buah alpukat adalah penentuan dosis konsumsi yang belum bisa ditakar oleh masyarakat dalam memberi manfaat menurunkan kolesterol. Namun, beberapa kekurangan dari buah alpukat, apabila dibandingkan dengan manfaatnya, maka buah alpukat memberikan manfaat yang jauh lebih besar dibandingkan dengan kekuranganya. ${ }^{30}$

\section{KESIMPULAN DAN SARAN}

Masalah PTM di Indonesia salah satunya dipicu oleh adanya hiperkolesterolemia. Prevalensi hiperkolesterolemia di Indonesia cukup tinggi yaitu berada diatas prevalensi hiperkoletserolemia di asia tenggara.

Hiperkolesterolemia didefinisikan sebagai peningkatan kadar kolesterol total dalam plasma lebih dari $200 \mathrm{mg} / \mathrm{dl}$. Kolesterol dapat menempel pada endotel pembuluh darah menyebabkan adanya disfungsi. Sehingga perfusi ke jaringan menjadi buruk. Hiperkolesterolemia memiliki hubungan yang erat dengan penyakit arterosklerosis, coronary artery diseas dan non alkoholik fatty liver.

Penggunaan obat-obatan dalam jangka waktu yang lama dapat menimbulkan berbagai efek samping. Alpukat memiliki peran dalam menurunkan kadar kolesterol karena banyak mengandung antioksidan dan monosaturated fatty acid yang menggantikan asam lemak jenuh dan terbukti menurunkan kolesterol dalam darah. Oleh karena itu alpukat sangat direkomendasikan oleh American Heart Association dalam panduan pola hidup untuk menurunkan risiko penyakit kardiovaskular. Buah alpukat ternyata tidak hanya dimanfaatkan buahnya saja, beberapa penelitian menggunakan ekstrak daunnya sebagai tatalaksana hiperkolesterolemia. Walaupun demikian, penelitian mengenai hal ini masih jarang dilakukan, sehingga diperlukan adanya penelitian-penelitian tambahan terkait hubungan buah alpukat terhadap menurunkan kadar kolesterol dalam darah.

\section{DAFTAR PUSTAKA}

1. Kementerian Kesehatan RI. Profil Kesehatan Indonesia Tahun 2010. Kementerian Kesehatan, editor. Jakarta: Kementerian Kesehatan RI; 2016. $198 \mathrm{p}$.

2. Kementerian Kesehatan RI. Kiat Menurunkan Kadar Kolesterol Jahat Dalam 7 Hari [Internet]. $2015 . \quad$ Available from: https://www.depkes.go.id/development/site/depke s/index.php?cid=1-15112600001\&id=kiat- 
menurunkan-kadar-kolesterol-jahat-dalam-7hari.html

3. WHO. Global Health Observatory (GHO) data:Raised cholesterol, Situation and trends [Internet]. 2008. Available from: https://www.who.int/gho/ncd/risk_factors/cholest erol text/en/

4. Kementerian Kesehatan RI. Riset Kesehatan Dasar (Riskesdas) 2013. Jakarta: Kementerian Kesehatan; 2013.

5. Kementerian Kesehatan RI. Laporan Nasional Riskesdas 2018. Kementerian Kesehatan RI, editor. Jakarta: BPPSDM Kemenkes RI; 2018.

6. Tan CX, Chong GH, Hamzah H, Ghazali HM. Effect of virgin avocado oil on diet-induced hypercholesterolemia in rats via $1 \mathrm{H}$ NMR-based metabolomics approach. Wiley Online Libr. 2018;32(11):2264-74.

7. Johari NZ, Ismail IS, Sulaiman MR, Abas F, Shaari K. Acute toxicity and metabolomics analysis of hypocholesterolemic effect of Mentha piperita aqueous extract in Wistar rats. Int J Appl Res Nat Prod. 2015;8(1).

8. Karr S. Epidemiology and Management of HyperlipidemiaEpidemiology and Management of Hyperlipidemia. AJMC [Internet]. 2017; Available from: https://www.ajmc.com/journals/supplement/2017 /pcsk9-inhibitors-a-guide-for-managedcare/epidemiology-and-management-ofhyperlipidemia-article

9. Dita MRA, Mukono IS, Rochmanti M. Combination Effect Of The Extract Of Avocado Leaf And Seed (Persea Americana) On Level Of Total Cholesterol, Ldl, And Hdl In Mice (Mus musculus) With Hypercholesterolemia. Biomol Heal Sci J. 2019;2(1):44-7.

10. Mohammad Yasir, Das S, Kharya M. The phytochemical and pharmacological profile of Persea americana Mill. Pharmacogn Rev. 2010;4(7):77-84.

11. Rahman S. Effect Of Avocades To Ldl Cholesterol As A Preventive Risk Of Atherosclerosis. Int $\mathbf{J}$ Multidiciplinary Curent Res. 2019;7(7).

12. Direktorat Jenderal Pelayanan Kesehatan. KOLESTEROL [Internet]. Kementrian Kesehatan RI. 2018 [cited 2019 Jul 13]. Available from: http://yankes.kemkes.go.id/read-kolesterol4619.html

13. Bunnoy A, Saenphet K, Lumyong S, Saenphet S, Chomdej S. Monascus purpureus-fermented Thai glutinous rice reduces blood and hepatic cholesterol and hepatic steatosis concentrations in diet-induced hypercholesterolemic rats. BMC Complement Med Ther [Internet]. 2015;15(88). Available from: https://www.ncbi.nlm.nih.gov/pmc/articles/PMC 4381394/

14. Stapleton PA, Goodwill AG, James ME, Brock RW, Frisbee JC. Hypercholesterolemia and microvascular dysfunction: interventional strategies. J Inflamm. 2010;7(54).
15. Cave A. Selective targeting of NADPH oxidase for cardiovascular protection. Curr Opin Pharmacol. 2009;9(2):208-13.

16. Liu P-Y, Liu Y-W, Lin L-J, Chen J-H, Liao JK. Evidence for Statin Pleiotropy in Humans Differential Effects of Statins and Ezetimibe on Rho-Associated Coiled-Coil Containing Protein Kinase Activity, Endothelial Function, and Inflammation. Circulation. 2009;131-8.

17. Badan Karantina Pertanian. Pedoman Sertifikasi Fitosanitari Buah Alpukat Indonesia. JAkarta: Kementerian Pertanian; 2015. 5 p.

18. Peou S, BrittanyMilliard, A.Shah S. Impact of avocado-enriched diets on plasma lipoproteins: A meta-analysis. J Clin Lipidol. 2016;10(1):161-71.

19. Go AS, Mozaffarian D, Roger VL, Benjamin EJ, Berry JD, Blaha MJ, et al. Heart Disease and Stroke Statistics-2014 Update. Circulation [Internet]. 2014;129: e28-e29. Available from: https://www.ahajournals.org/doi/full/10.1161/01. cir.0000441139.02102.80

20. Eckel RH, Jakicic JM, Ard JD, Jesus JM de, Miller $\mathrm{NH}$, Hubbard VS, et al. 2013 AHA/ACC Guideline on Lifestyle Management to Reduce Cardiovascular Risk A Report of the American College of Cardiology/American Heart Association Task Force on Practice Guidelines. Circulation. 2013;129(25).

21. Soleha M. Kadar Kolesterol Tinggi Dan FaktorFaktor Yang Berpengaruh Terhadap Kadar Kolesterol Darah. J Biotek Medisiana Indones. 2012;1(2):85-92.

22. Karam I, Yang YJ, Li JY. Hyperlipidemia Background and Progress. SM Atheroscler J. 2017;1(1):1-8.

23. G. P, Xenoulis, M.Steiner J. Lipid metabolism and hyperlipidemia in dogs. Vet J. 2010;183(1):12-21.

24. Karam I, Ma N, Liu X-W, Li S-H, Kong X-J, Li J$\mathrm{Y}$, et al. Regulation effect of Aspirin Eugenol Ester on blood lipids in Wistar rats with hyperlipidemia. BMC Vet Res. 2015;(217).

25. Tarantino N, Santoro F, Gennaro L De, Correale M, Guastafierro F, Gaglione A, et al. Fenofibrate/simvastatin fixed-dose combination in the treatment of mixed dyslipidemia: safety, efficacy, and place in therapy. Vasc Health Risk Manag. 2017;13:29-41.

26. Global Burden of Disease Study 2013 Collaborators. Global, regional, and national incidence, prevalence, and years lived with disability for 301 acute and chronic diseases and injuries in 188 countries, 1990-2013: a systematic analysis for the Global Burden of Disease Study 2013. Lancet. 2015;386(9995):743-800.

27. Nelson RH. Hyperlipidemia as a Risk Factor for Cardiovascular Disease. Prim Care. 2012;40:195211.

28. Carvajal O, Nolasco C, Aguilar G, Melo G, Hayward PM, Barradas DM. Avocado oil supplementation modifies cardiovascular risk profile markers in a rat model of sucrose induced metabolic changes. Hindawi Publ Corp. 2014;2014. 
29. Cho LW. The metabolic syndrome. Singapore Med J. 2011;55(11):779-85.

30. Noorul H, Nesar A, Zafar K, Khalid M, Zeeshan A, Vartika S. Health benefits and pharmacology of Persea americana mill . (Avocado) International Journal of Research in Health benefits and pharmacology of Persea americana mill .(Avocado ). Int J Res Pharmacol Pharmacother. 2016;5(2).

31. Blickstein D, Shaklai M, Inbal A. Warfarin antagonism by avocado. Lancet J. 1991;April. 